Research Journal of Applied Sciences 6 (2): 110-115, 2011

ISSN: $1815-932 \mathrm{X}$

(C) Medwell Journals, 2011

\title{
Design of Building Integrated Photovoltaic System for a Low Energy Residences in Hot Dry Climatic Conditions in Khartoum
}

\author{
${ }^{1}$ Zeinab Abdallah M. Elhassan, ${ }^{1}$ Muhammad Fauzi. Moh. Zain, \\ ${ }^{2}$ Kamaruzzaman Sopian and ${ }^{1}$ Arafa Awadalla \\ ${ }^{1}$ Department of Architecture Engineering, Faculty of Engineering and Built of Environment, \\ University Kebangsaan Malaysia, 43600 UKM, Bangi, Selangor D.E., Malaysia \\ ${ }^{2}$ Department of Mechanical and Material Engineering, \\ University Kebangsaan Malaysia, 43600 UKM Bangi, Selangor Darul Ehsan, Malaysia
}

\begin{abstract}
This study search to find out of building integrated photovoltaic a system designs in Khartoum. It discussed technical issues and design an integrated of photovoltaic in domestic using within an urban approach towards sustainability in energy. Photovoltaic systems can be used to develop the solar energy in almost all kinds of applications. Exploiting of solar energy for domestic use is one avenue where the energy produce from the sun is converted into electricity to power most if not all the appliances available at the homes and residences. Building a photovoltaic system is the process of designing, selecting and calculating the ratings of the equipments employed in the system. This process depends on a range of factors such as geographical location, solar irradiation and load requirements. Researcher introduce the procedures utilize in building and selecting the equipments of a grid-connected photovoltaic system based on the Watt-Hour demand was $3.8 \mathrm{~kW}$. As a case study, a residence in Khartoum with low energy consumption is selected.
\end{abstract}

Key words: Buildings, urban approch, photovoltaic system, solar energy, Khartoum, Malaysia

\section{INTRODUCTION}

Building Integrated Photovoltaic's (BIPV) is a PV application close to being capable of delivering electricity at less than the cost of grid electricity to end users in certain peak demand niche markets (Blanton et al., 1996). BIPV acceptance varies seriously by and within, country depending upon climate, built environment, electricity industry structure, government policies, local product offerings, market stimulation mechanisms, consumer demand, existing industrial capabilities and the forms of tariffarrangementfor grid-connected PV power generation (Green, 2003; Bakos et al., 2003; Watt et al., 1997; Nieuwenhout et al., 2001; Mason et al., 1997) experience with solar homesystemsin developing countries. BIPV grid connected system involves combining solar photovoltaic electricity technologies with those of building construction (Schmid, 1992).

The fields of energy conservation and building design. However cannot be underestimated in the context of the more familiar notion of sustainable development (Kaldellis et al., 2004). The concept of sustainability is more relevant that ever support systems which using in sustainable energy the common used was BIPV (Moharil and Kulkarni, 2009). The essential aspects, sustainability of energy must become the cornerstone of the researchers design philosophy. It processes the design sustainable buildings that rely on renewable resources to provide most and eventually all of their own energy need (Beerbaum and Weinrebe, 2000). It the most promising renewable energy technologies are Photovoltaic (PV) power (Chaurey et al., 2004). PV power is a truly elegant means of producing on-site electricity. The important feature which influences of design the sustainable house was climate and solar radiation at the case study location. The climate of Khartoum in the summers are invariably hot (mean max. $41^{\circ} \mathrm{C}$ and mean min. $25^{\circ} \mathrm{C}$ ) with large variation; low relative humidity averages $(25 \%)$.

Winters can be quite cool. Sunshine is very prevalent. Dust storms occur in summer (Alnaser et al., 2007). The climate is a typical desert climate where rain is infrequent and annual variation in temperature is large. Khartoum is located at 15.38 latitude and 32.28 longitudes. Energy planners have long envisioned large utility-scale solar power plants covering large expanses of desert (Alnaser et al., 2007). Energy planners have long

Corresponding Author: Zeinab Abdallah M. Elhassan, Department of Architecture Engineering,

Faculty of Engineering and Built of Environment, University Kebangsaan Malaysia, 43600 UKM, Bangi, Selangor D.E., Malaysia 
envisioned large utility-scale solar power plants covering large expanses of desert. While this vision has many favorable attributes, the economics require careful investigation. Grid connected PV systems require the allocation of land (Markvart, 2000) which must be acquired and prepared to accept the PV system (Billinton and Karki, 2003) the cost of land and the site work must considerable. In Sudan the lack of available large open tracts of land has effectively precluded the large-scale grid connected of PV system option as afforded to develop in Sudan Renewable energy resources for electricity generation in Sudan (Omer, 2007). The residential sector consumes upwards of $17 \%$ electrical energy in Sudan (Omer, 2007). More than $80 \%$ of this is generated using fossil fuels that contribute immensely to environmental pollution and global warming. The use of energy efficient measures and renewable energy, complimenting fossil fuels can reduce electrical power outages during peak demand and more importantly, cause a reduction of gaseous pollutants. BIPV can be of the form of:

- Roofing materials

- Wall and fenestration materials (Bendel et al., 2008)

- Flexible photovoltaic modules and can be integrated to the roof of new buildings or where major roof replacement is undertaken

Methods of integration include exchangeable PV shingles, prefabricated PV roof panels and insulated PV roof panels (Mallick et al., 2004). Fully integrated BIPV roofing systems must perform the function of a standard roof and provide water tightness, drainage and insulation. Most retrofitted roof-mounted systems are though not however fully integrated into the roof structure. Roofs offer an attractive location for BIPV.

\section{MATERIALS AND METHODS}

Procedure of designs: The system was designed for maximum output in summer and has an acceptance half-angle of $36^{\circ}$ providingacollection time of $7 \mathrm{~h}$ was characterised experimentally for high-latitude bi-facial cell BIPV applications (Adsten, 2002). Different configurations were made for grid connected, roof integrated, East/West, spring/fall and wall integration. A cross-section of a is shown in (Adsten, 2002). Illustrates that the cross-section of roof integrated designed for Stockholm conditions (Adsten, 2002). The highest optical efficiency reported was $56 \%$ forabi-facial based on BIPV on a roof. In contrast, optical efficiency of $91 \%$ was predicted for dielectric-filled BIPV covers and $85 \%$ for an air-filled a symmetric CPC BIPV system (Mallick et al., 2004; Eames et al., 2001). Design establish the number of modules, the dimensions of the modules and the total dimensions of the system to be integrated into a roof. In this case is avoided some modules have integrated diodes to make a short cut when a row of cells is covered or shaded. AC modules also must be isolate the impact of shading as each module's that mean shading was avoided, DC power output is converted to AC and drawn individually with a converter. In this case to get the power which was load at the sustainable house photovoltaic technologies with Polycrystalline cells are less impacted by irregular shading effects due to different electrical connection characteristics and better performance in low light. Inverter characteristics are also critical, since most have a cut-off point. In general, shading should be avoided as a possible (Zahedi and Smieee, 1998).

A fully integrated single house design item (Markvart et al., 2006). Although, the architect may creative decisions are needed from the start in particular (Zahedi and Smieee, 1998) from structural and building services engineers. And get information and ideas about energy and comfort systems and structural design. With all technical requirement as shown in Table 1. Designs at AL-Azhari city in Khartoum state converting sunlight into electricity through the use of PV cells as part of integrated building systems is an appropriate way of accessing renewable energy. The PV conversion process is silent has no moving parts and is pollution-free. The vast areas offered by the roofs. The slope angle $(\beta)$ with the roof is define as the angle between the plane of the solar collector in question and the horizontal as shown in Fig. $1(\beta)$ is positive, the orientation of the surface is toward the equator and when negative, it is toward the pole (Bari, 2000). The optimum design of a BIPV system although based on a building's electrical load profile, PV output and balance of system characteristics must be cognoscenti of building design constraints, building location, offset costs, climate and future load growth (Watt et al., 1997). System economic viability depends on local electrical loads and utility prices (Mondol et al., 2006; Mallick et al., 2001). Approximately 25-30\% (Sick and Erge, 1996) of energy consumed in buildings in industrialised countries is as electricity. Photovoltaic can be integrated on virtually every conceivable structure

Table 1: With system architecture summary

\begin{tabular}{ll}
\hline Component & Characteristics \\
\hline PV system power & $5 \mathrm{~kW}$ \\
Type of building & Roofing tile PV \\
Integration & Integration and double-Glazed PV glass integration \\
Type of cell & Mono-cry stalline silicon \\
Technology & Cell (roof) and Poly-crystalline silicon cells (windows) \\
Array dimensions & $34.2 \mathrm{~m}^{2}$ \\
Weight & $120 \mathrm{~kg}$ (double-glazed PV glass) \\
Inverter & Line Back FX (Nihon Den chi Co. Ltd.) 4.5 kVA \\
Monitoring & $\begin{array}{l}\text { Horizontal pyrheliometer, inclined phyheliometer, } \\
\text { air temperature }\end{array}$ \\
\hline
\end{tabular}




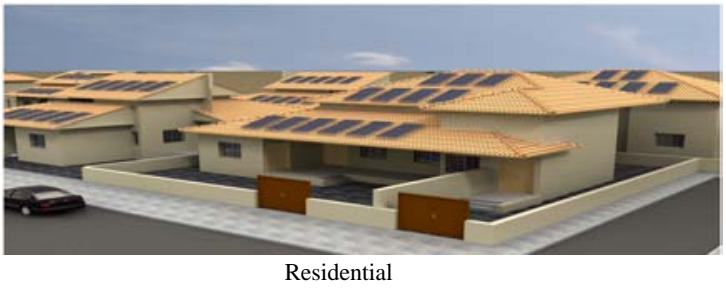

Fig. 1: Installation photovoltaic module

from bus shelters to high rise buildings. BIPV modules fabricated directly onto building materials can in highvolume production lead to lower substrate, distribution and installation costs ( $\mathrm{Ji}$ et al., 2008).

\section{RESULTS AND DISCUSSION}

Design of (BIPV) house in Khartoum of $3.8 \mathrm{~kW}^{\text {day }}{ }^{-1}$ depends mainly of installing PVC panels in italics ceilings (Bungalow) and connection of batteries with internal network of solar house, in addition to that home connection with the National electricity network to allow some part of the house to use public network electricity and other part could use PVC electricity.

At $23^{\circ}$ until it is completely attack of direct sun angle during the day. Figure 1 shows the position of the sun at solar noon a PV panel oriented to the north and titled at the slope of roof (Hankins et al., 1995; Fur Sonnenenergie, 2008). The direction of North and South with $23^{\circ}$ is restricted fully ventilated in the state of Khartoum.

Of the location this deals with (Abu-Jasser, 2010) that obtained can considered the roof-top mounting system as on-roof mounting, leaving the existing roofing material in place and in-roof mounting where the modules take over the function of the roof tiles that obtain the position of system and the tilt of roof was influence of the successful capture the solar radiation and functional architeure design as resulted (Abu-Jasser, 2010).

Installation of orientation of modules and the roof: The roofs was directed towards the east inclined to north direction depend on and towards west inclined to south direction (Alnaser et al., 2004). The sun in the Sudan in most hours of day which represents the capacity that will allow the solar panels work since it was sunrise and $12: 30 \mathrm{pm}$ in summer until 1:30 pm in winter, sun direction is towards east then changed direction from $12: 30 \mathrm{pm}$ in summerand 1:30 pm winter until sunset towards the west (Markvart et al., 2006; Stackhouse and Whitlock, 2009) was deals with this result that obtained the optimum time to get maximum power was12-1:30 as optimum time to capture most of solar radiation depend on the result of solar radiation as shown in Fig. 2, according to geographical mandate studies of Khartoum state, the

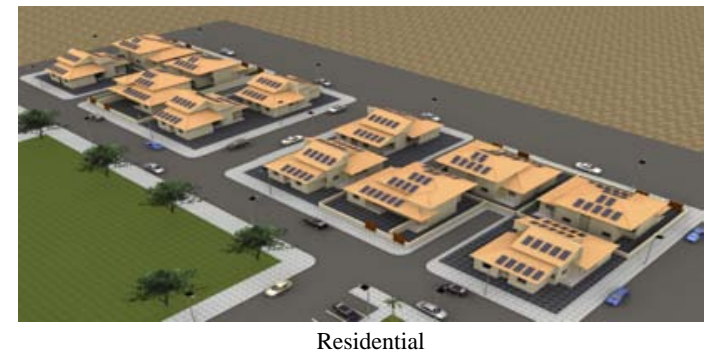

Fig. 2: Planning of residence in Khartoum

roofs was directed towards east and west with an incline he find that. The geographical location of the Gaza strip makes it one of the relatively sun-rich regions in the globe. It is located in the northern hemisphere area of the earth at $31.3^{\circ}$ latitude and $34.3^{\circ}$ longitude with an annual incident solar irradiance of about $2000 \mathrm{kWh} \mathrm{m}^{-2}$ (Markvart, 2000). This implies that the solar panel must be mounted facing the south to capture a maximum amount of solar energy and the number of days of autonomy where the system will operate without receiving an input charge from the sun is approximated to 4 days according to the record (Moharil and Kulkarni, 2009; Borowy and Salameh, 2002) converse, the minimum and maximum power generated values are obtained from historical data and their effect on demand is also studied. The loss of load hours is calculated considering the power generation and load requirement of different months with a different locations.

That mean the optimum angle of slope of roof was $23.5^{\circ}$ at Khartoum to get the maximum power, the status of each of those considerations must be included in the design models for BIPV (Omer, 2007). The single house contains the different activities of a housing as the bedroom, living room, a reception and a small kitchen serves medium and large family depending on the model that ranging from of that of two rooms and a reception for men, another for women and various bath rooms and the largest model in three sleeping rooms and reception for men, another for women and various bath rooms. Those activities load was $3.8 \mathrm{~kW}$ day $^{-1}$ as results for different appliances for single home user load It has been found that for this system each home user consume energy around ( $224 \mathrm{~W}$ day $^{-1}$ of $\mathrm{Wh} \mathrm{day}^{-1}$ ) with a peak demand of nearly as shown in Table 1. The system also gives the opportunity for expanding its capacity in order to manage with the increasing demand in the future (Masters, 2004).

This was done by increasing either the rated power of diesel generator, renewable generator or both of them (Nayar et al., 1993). As find the maximum load was 4.8 in Gaza and (Sasitharanuwat et al., 2007) was find that. This mode of operation is particularly suitable for systems with relatively small renewable energy penetrations that obtained the size of the system in small sizing of 
renewable energy using BIPV was depends on the load and suitability of whole system component. PV system was positioned upon the roof and distant from the first PV modules was thought to be appropriate over the life of the building when other PV sub-arrays will be positioned much closer to it (Sims et al., 2003). If more space for PV equipment became necessary because the area was approximately $40 \mathrm{~m}^{2}$ required for standard equipment in the system design in this case and approximately $10 \mathrm{~m}^{2}$ of additional space is required for PV related equipment.

Thus the PV plant floor area is about $4-5 \%$ of the total array area (Sims et al., 2003; Shrestha and Goel, 1998) find as the result the issues in optimizing the use of isolated small PV power generation in remote areas and revealed the procedure to evaluate different PV method considering the stochastic nature of the insulation and the load requirement that acquire the installation of the grid connected system has a most important command factor of evaluate the success which is the construction way and the functional design.

Tilt roof of building integrating photovoltaic: Sloped roof constructions are very common for residential buildings and are most suited for a PV installation if orientated approximately towards the equator. The roof systems are particularly useful for sites situated towards the quarter where overhead sunlight is predominant as shown in (Fig. 2). Form and color of modules and system cells are typically, dark blue in color. Different colors of the type of module also has an impact on color (Emmanuel, 2005). Frameless modules give a very harmonious impression as the roof is not disturbed by frame patterns of different color or material to that of the cells as shown in Fig. 2. (Benemann et al., 2001; Celik, 2002) was smaller frames in the same color as the cells are almost invisible at the surface.

Planning concern of installation: The calculation of the residential sector is composed around a service center the group of neighborhood housing and which a service center is provided that contains the basic services needed as shown in Fig. 2 (Dalton et al., 2009) planning used that kind of technology in supplying energy as indicated by the figures of design and planning it implemented in this study as the rules of planning. As we shown in Fig. 2 the amount of irradiation in the residence depends on the latitude of the building and the local climate as (Dalton et al., 2009) found to get a perfect design. The maximum irradiation depends on the orientation and the angle of the collection surfaces also put in consider for latitudes $32^{\circ}$ north good results (over 90\%) can be achieved between southeast and southwest with system tilt angles $23^{\circ}$ as shown in Fig. 1. Orientations between east and southeast and between southwest and west are acceptable for tilt angle $23^{\circ}$. Those agree with
Kaldellis et al. (2004) was get that determined the optimum dimensions of an appropriate stand-alone photovoltaic system, able to guarantee the coverage of remote consumers energy demand located area. A detailed energy balance analysis of selected photovoltaic system was done on an hourly basis Kaldellis et al. (2004) Abu-Jasser (2010) results that. The equipments used to construct the stand-alone photovoltaic system for the suggested remote residence described above are summarized with some details and specifications in table which define his load in Gaza that obtain that the electrical appliances available at the residence are itemized with their power ratings and time of operation during the day to obtain the average energy demand in Watt-hour per day.

The constraint and economics: The life time has been considered to be 25 years and the annual real interest rate has been taken as $4 \%$. As the system has been designed for single and also for multiple home users like 10-50 but the load consumed by the user is low so operation and maintenance cost has been taken 500 SP year ${ }^{-1}$. There is no capacity shortage for the system and operating reserve is $10 \%$ of hourly load. Analysis shows that the cost of energy (KWH) is low for the system which is the combination of 50 homes (Fuentes and Roaf, 1999). The load demand for each combination of homes with system architecture and financial summary (Moharil and Kulkarni, 2009).

The system simulations showed that with a daily load of $207 \mathrm{kWh}$ day $^{-1}$ the combination of a $12 \mathrm{KWp}, \mathrm{PV}$ system with a battery backup capacity of $108 \mathrm{kWh}$ would be optimum given the most suitable strategy for the use of two differently sized solar renewable energy generators now present (Moharil and Kulkarni, 2009). Yearly system performance of autonomous photovoltaic energy systems with battery storage and simulated using the predetermined combinations. That mean It was shown that the yearly system performance predicted from the 3 and 4 day synthetic data closely agreed with that obtained from the measured data, varying only slightly for different combinations that obtained the reported development of computer approach for evaluating general performance of grid connect PV system.

\section{CONCLUSION}

Design small-scale of housing developments is apparent with whole requirement of urban planning and technical solution of BIPV grid connected system. Design was developed and structure which implement the housing construction process are presented with numerous opportunities for PV roof integration in single-family houses, $10,20,50$ and for roof integration in 
single house. To complete the incomplete electricity which provide. This allows for the integration of a many numbers of PV systems during construction Integration of PV systems in residential homes to generate the maximum power from the system with definite load $3.8 \mathrm{~kW} \mathrm{day}^{-1}$ for single house in Khartoum-Alazhari city can be carried out on and basis but often. The designer began to investigate layouts that would maximize solar potential, considering day lighting; passive solar gain and the use of PV module.

\section{ACKNOWLEDGEMENTS}

The researchers would like to thank Prof. Dr. Muhammad Fauzi Mohd. Zain, for his support and fully accommodating and providing the necessary equipment and to give the principals of scientific experience in this area and thanks Prof. Dr. Kamaruzzaman Sopian for providing necessary information about BIPV and software, researchers express his blessing for all members of SUCOM group for their cooperative.

\section{REFERENCES}

Abu-Jasser, A., 2010. A stand-alone photovoltaic system, case study: A residence in Gaza. J. Applied Sci. Environ. Sanitation, 5: 81-91.

Adsten, M., 2002. Solar Thermal Collectors at High Latitudes: Design and Performance of Non-Tracking Concentrators. Universitet/Acta Universitatis Uppsaliensis, Sweden, ISBN-13: 9789155452742 , pp: 78.

Alnaser, W.E., B. Eliagoubi, A. Al-Kalak, H. Trabelsi, M. Al-Maalej, H.M. El-Sayed and M. Alloush, 2004. First solar radiation atlas for the Arab world. Renewable Energy, 29: 1085-1107.

Alnaser, W.E., F. Trieb and G. Knies, 2007. Solar energy technology in the Middle East and North Africa (MENA) for sustainable energy, water and environment. Adv. Solar Energy, 17: 261-304.

Bakos, G.C., M. Soursos and N.F. Tsagas, 2003. Technoeconomic assessment of a building-integrated PV system for electrical energy saving in residential sector. Energy Build., 35: 757-762.

Bari, S., 2000. Optimum slope angle and orientation of solar collectors for different periods of possible Utilization. Energy Convers. Manage., 41: 855-860.

Beerbaum, S. and G. Weinrebe, 2000. Solar thermal power generation in India: A techno-economic analysis. Renewable Energy, 21: 153-174.
Bendel, C., P. Funtan, T. Glotzbach, J. Kirchhof and G. Klein, 2008. Results of the optinos project-deficits and unsureness in test procedures of Photovoltaic inverters. Proceedings of the 23rd European Photovoltaic Solar Energy Conference and Exhibition, Feria Valencia, Sept. 1-5, Valencia, Spain, pp: 1-5.

Benemann, J., O. Chehab and E. Schaar-Gabriel, 2001. Building-integrated PV modules. Solar Energy Mater. Solar Cells, 67: 345-354.

Billinton, R. and R. Karki, 2003. Reliability/cost implications of utilizing photovoltaics in small isolated power systems. Reliable Eng. Syst. Safety, 79: 11-16.

Blanton, S.A., M.A. Hines and P. Guyot-Sionnest, 1996. Photoluminescence wandering in single CdSe nanocrystals. Applied Phys. Lett., 69: 3905-3907.

Borowy, B.S. and Z.M. Salameh, 2002. Optimum photovoltaic array size for a hybrid wind/PV system. IEEE Trans. Energy Convers., 9: 482-488.

Celik, A.N., 2002. The system performance of autonomous photovoltaic-wind hybrid energy systems using synthetically generated weather data. Renewable Energy, 27: 107-121.

Chaurey, A., M. Ranganathan and P. Mohanty, 2004. Electricity access for geographically disadvantaged rural communities technology and policy insights. Energy Policy, 32: 1693-1705.

Dalton, G.J., D.A. Lockington and T.E. Baldock, 2009. Feasibility analysis of renewable energy supply options for a grid-connected large hotel. Renewable Energy, 34: 955-964.

Eames, P.C., M. Smyth and B. Norton, 2001. The experimental validation of a comprehensive unified model for optics and heat transfer in line-axis solar energy systems. Solar Energy, 71: 121-133.

Emmanuel, M.R., 2005. An Urban Approach to ClimateSensitive Design: Strategies for the Tropics. Taylor and Francis, London, ISBN-13: 9780415334099.

Fuentes, M. and S. Roaf, 1999. Demonstration project for a $4 \mathrm{KW}$ domestic photovoltaic roof in Oxford. Vol. 1, ETSU Final Report, ETSU S/P2/00236/00/01, Enero 1999.

Fur Sonnenenergie, D.G., 2008. Planning and Installing Photovoltaic Systems: A Guide for Installers, Architects and Engineers. 2nd Edn., Earthscan, London, UK., ISBN-13: 9781844074426.

Green, M.A., 2003. Crystalline and thin-film silicon solar cells: State of the art and future potential. Solar Energy, 74: 181-192.

Hankins. M., F. Njeru and M. Glen-Williamson, 1995. Solar Electric Systems for Africa: A Guide for Planning and Installing. 2nd Edn., Commonwealth Secretariat, Lonson, ISBN-13: 978-0850924534, pp: 136. 
Ji, J., G. Pei, T.T. Chow, K. Liu, H. He, J. Lu and C. Han, 2008. Experimental study of photovoltaic solar assisted heat pump system. Solar Energy, 82: 43-52.

Kaldellis, J.K., P. Koronakis and K. Kavadias, 2004. Energy balance analysis of a stand-alone photovoltaic system, including variable system reliability impact. Renewable Energy, 29: 1161-1180.

Mallick, T.K., P.C. Eames and B. Norton, 2001. Thermooptical analysis of asymmetric compound parabolic photovoltaic, concentrator for building integration in the UK. Proceedings of the Renewable Energy in Maritime Island Climates, Solar Energy Society Conference C76, Sept. 1, Belfast, pp: 135-142.

Mallick, T.K., P.C. Eames, T.J. Hyde and B. Norton, 2004. The design and experimental characterisation of an asymmetric compound parabolic photovoltaic concentrator for building facade integration in the UK. Solar Energy, 77: 319-327.

Markvart, T., 2000. Solar Electricity. John Wiley and Sons, New York, ISBN: 0471988529, pp: 280.

Markvart, T., A. Fragaki and J.N. Ross, 2006. PV system sizing using observed time series of solar radiation. Solar Energy, 80: 46-50.

Mason, N.B., T.M. Bruton and K.C. Heasman, 1997. $\mathrm{KWh} / \mathrm{kWp}$ energy production from LGBG cell modules in Northern Europe. Paper Presented at the 12th German National PV Symposium Staffelstein.

Masters, G.M., 2004. Renewable and Efficient Electric Power Systems. Wiley-IEEE Press, USA., ISBN-13: 9780471280606, pp: 680.

Moharil, R.M. and P.S. Kulkarni, 2009. A case study of solar photovoltaic power system at Sagardeep Island, India. Renewable Sustainable Energy Rev., 13: 673-681.

Mondol, J.D., Y.G. Yohanis and B. Norton, 2006. Optimal sizing of array and inverter for grid-connected photovoltaic systems. Solar Energy, 80: 1517-1539.

Nayar, C.V., S.J. Phillips, W.L. James, T.L. Pryor and D. Remmer, 1993. Novel wind/diesel/battery hybrid energy system. Solar Energy, 51: 65-78.
Nieuwenhout, F.D.J., A. van Dijk, P.E. Lasschuit, G. van Roekel and V.A.P. van Dijk et al., 2001. Experience with solar home systems in developing countries: A review. Progress Photovoltaics: Res. Appl., 9: 455-474.

Omer, A.M., 2007. Renewable energy resources for electricity generation in Sudan. Renewable Sustainable Energy Rev., 11: 1481-1497.

Sasitharanuwat, A., W. Rakwichian, N. Ketjoy and S. Yammen, 2007. Performance evaluation of a $10 \mathrm{kWP}$ PV power system prototype for isolated building in Thailand. Renewable Energy, 32: 1288-1300.

Schmid, J., 1992. PV in buildings. Proceedings of the 11th EC Photovoltaic Solar Energy Conference, Oct, 12-16, Montreux, Switzerland, pp: 1659-1663.

Shrestha, G.B. and L. Goel, 1998. A study on optimal sizing of stand-alone photovoltaic stations. IEEE Trans Energy Conver., 13: 373-378.

Sick, F. and T. Erge, 1996. Photovoltaics in Buildings: A Design Handbook for Architects and Engineers. James and James (Science Publisher) Ltd., London, pp: 287.

Sims, R.E.H., H.H. Rogner and K. Gregory, 2003. Carbon emission and mitigation cost comparisons between fossil fuel, nuclear and renewable energy resources for electricity generation. Energy Policy, 31: 1315-1326.

Stackhouse, P.W. and C.H. Whitlock, 2009. Surface meteorology and Solar Energy. Release 6.0 Methodology, NASA SSE 6.0. Earth Science Enterprise Program, National Aeronautic and Space Administration(NASA), Langley. http://eosweb.larc. nasa.gov/sse/.

Watt, M., R.J. Kaye, D. Travers and I. MacGill, 1997. Assessing the potential for PV in buildings. Proceedings of the 14th European Photovoltaic Solar Energy Conference, June 30-4 July, Barcelona, Spain, pp: 232-235.

Zahedi, A. and Smieee, 1998. Development of an electrical model for a PV/battery system for performance prediction. Renewable Energy, 15: 531-534. 